\title{
Research on Ideological and political education paradigms
}

\author{
Wen Huiqi \\ zhejiang university school of Marxism, \\ zhejiang Hangzhou, 310000, China \\ e-mail: 383455625@qq.com
}

\begin{abstract}
The paradigm of ideological and political education is a hot issue in the study of ideological and political education in recent years. The exploration and thinking of the paradigm problem is in the ascendant period. The paradigms of ideological and political education has four stages: the stage of pre-paradigm, normal paradigm, paradigm conflict and paradigm development. The research achievements of the academic community have a positive impact on the problems of strengthening the discipline, enhancing the self-confidence of the subject, and solving the problem of "inefficient problem solving". This paper shows the active concern and extensive thinking of domestic scholars on the problem of education research paradigm.
\end{abstract}

Keywords-Ideological and Political Education; Paradigm; Four stages

\section{PHASE ONE: IDEOLOGICAL AND POLITICAL} EDUCATION'S PRE-PARADIGM

This is called the pre-paradigm stage. Because this period is still in start-up period of ideological and political education. Many of the works are during the 1980s and 1990s.For example, Introduction to ideological and political work, Principles of ideological and political education, Introduction to political work and so on. The concrete expression is three kinds of ideological and political education paradigm. They are: A paradigm of ideological and political work, classical educational paradigm, and the military political work paradigm. First of all, A paradigm of ideological and political work is mainly reflected in the research achievements of central and local propaganda systems, party schools and enterprises. Its theory comes from a summary of the lessons learned from the education practice. The unity of academic discourse and document discourse is its important feature. Secondly, It is classical educational paradigm, this paradigm is based on the pedagogical paradigm, and is a paradigm of ideological and political education based on the pedagogical paradigm. Education (especially moral education) is the theoretical source and basic framework. Its professional vocabulary is mainly educational and psychological terms. Thirdly, It is the military political work paradigm. It mainly reflects in the research achievements of military ideological and political work, the research object mainly focuses on military ideology and politics. The theoretical source is mainly the ideological and political education thought of the party and military leaders in the period of revolution and construction, as well as the practical experience of the army's ideological and political work. There are other paradigms, too. For example, the personality center paradigm, the education ecological paradigm, social system theory paradigm, the paradigm of ideological relations and so on.

The pre-paradigm phase of the education paradigm of ideological politics was mainly focused on the early stage of ideological and political education in the 1980s and 1990s.Ideological and political education has just been established. It is not even completely divorced from the ideological and political work system. Academic research and practical work are not completely divorced. The main problems are: Firstly, the borrowing of other disciplinary paradigms has not formed the unique paradigm of the ideological and political education discipline. Second, the proposal and construction of the education paradigm of ideological and political science is based on empirical 
summation, rather than a strict model, which is the uniform pattern that the academic community must follow. Third, there is no unified, universally recognized or relatively centralized ideological and political education research paradigm, which is fragmented, chaotic and self-speaking.

\section{Phase TWO: IDEOLOGICAL AND POLITICAL EDUCATION'S NORMAL PARADIGM}

At this stage, the education research paradigm of ideological and political science gradually formed two stable and recognized paradigms: the human learning paradigm and the social philosophy paradigm of ideological and political education. The formal proposal and establishment of the anthropological paradigm of education research on ideological and political science is marked by professor zhang yao-can's two articles in 2010.One is the study of "the human transformation of education research paradigm", which was published in the journal of education college in guangxi in 2010.Another one is in the study of the education research, "the study of the human learning paradigm of education research paradigm". The publication of these two articles marks the formal proposal of the research paradigm of ideological and political education in the subject of ideological and political education. Great influence has been created in the learning circle. Except professor zhang yaocan, The representative scholars of the research paradigm of ideological and political education in the academic community include professor chu fengying, professor zhang shujun and professor Lin bohai.

The specific title of the social philosophical paradigm of education research is actually established with the development of the human paradigm. In fact, the philosophical paradigm of the education research has long been "unmarked". The research on the philosophical paradigm of education is also presented and discussed in the comparative study of human learning paradigm. The influence of traditional Chinese culture and certain historical conditions has long been used in the ideological and political education in China. It has played a huge positive role in maintaining social stability and promoting economic development. Our current ideological and political education obviously leans towards the "social philosophy" paradigm.

In the normal paradigm stage, the researchers of ideological and political education conduct in-depth research and exploration in their respective paradigms. But this kind of "separate politics" research method is not conducive to the formation of unified, integrated ideological and political education research paradigm. It is also not conducive to the holistic advancement of the ideological and political education discipline

\section{PHASE THREE: IDEOLOGICAL AND POLITICAL EDUCATION'S PARADIGM CONFLICT}

At this stage, the paradigm conflict focuses on the conflict between the social philosophy paradigm and the human paradigm. One view holds that the social philosophy paradigm of education research should be upheld, and the transformation of the human paradigm in the research of ideological and political education is put forward. Another view is that the philosophical paradigm of the education research of ideology has long been unsuitable for the market-oriented transformation of Chinese society. In particular, the development of socialism with Chinese characteristics in the new era should promote the transformation of the anthropological paradigm of the education research of ideology and politics as soon as possible. "It seems to have become the consensus of the academic world that the promotion of the ideological and political education is transformed from the social philosophy paradigm to the human paradigm, but just make a serious reflection on the human paradigm. It's not hard to see, there are three paradoxical problems in the study of human paradigm, and advocated to return to the social philosophical paradigm. "

During the phase of the paradigm conflict, scholars debate whether to realize the transformation from the social philosophy paradigm to the human paradigm. This is to some extent the scholars' extremely cautious attitude towards the paradigm shift. On the whole, most scholars have opposed the social philosophy paradigm in the education research paradigm. In fact, does the social philosophy paradigm and 
the paradigm of human learning in the education study of ideology really only get into the possibility of confrontation and endless debate without integration? In the fourth stage of the education research paradigm of thought politics, scholars have responded positively and actively to the possibility of the integration of the paradigm.

\section{PHASE FOUR: IDEOLOGICAL AND POLITICAL EDUCATION'S PARADIGM DEVELOPMENT}

In the fourth stage, the exploration of the education research paradigm of ideology and politics is more in-depth and presents the trend of integration in general. This also proves that the endless debate between the social philosophy paradigm and the human paradigm of the education study of the ideological and political education is over. Representative scholars include: Professor Chen binggong thinks that, "Ideological and political education should advocate the "integration duality" paradigm. The so-called 'integration' means that the noumenon of ideological and political education is a unified organic whole. So-called "duality" refers to the ideological and political education inherently contains two basic aspects, namely service for the social development and service for human development. They are interconnected, constrained, transformed and integrated. The two aspects should not be separated and opposed to one another."
Bing-gong Chen, professor of "integration of duality paradigm" as a "solution" for both the debate a tentative exploration for us to explore the development of ideological and political education paradigm provides a new train of thought. It has groundbreaking value and inspiring value. This greatly enriches the paradigm study of ideological and political education. But at the same time, we should also see, the "integration duality" paradigm of ideological and political education is "one's own words". The study of this kind of paradigm is relatively thin, far from the social philosophy paradigm of ideological politics education and the abundant data of human learning paradigm. But it also shows that this paradigm has great scope for exploration. This is the task of the next paper.

\section{REFERENCES}

[1] Chen bingogn. On the "integration duality" paradigm of ideological and political education [J]. Teaching and research, 2016, (08):50-58.

[2] Yang zengdong. Analysis on the research paradigm of ideological and political education [J].Think education research, 2013, (12):28-32.

[3] Tao lei, Huang mingli. The human learning paradigm or the social philosophy paradigm? _ Reflection on modern transformation of thought politics education [J]. explore, 2011, (06):120-125+169.

[4] Pei min. Research paradigm of ideological and political work [J]. The study of political work, 2005, (18):10.

[5] Zhang yaocan. To promote the transformation of the research paradigm of ideological and political education [J].Think education research, 2010, (07):3-6. 